by P. A. White, Y-S. Hong and R. R. Reeves

\title{
Long-term sustainability of groundwater resources: an approach using integrated hydrogeological and economic models
}

Institute of Geological \& Nuclear Sciences, Private Bag 2000, Taupo, New Zealand

Groundwater is an important but under-utilised water resource. Its use is growing. Approaches to the management of groundwater are evolving, with sustainability as the current approach in New Zealand, and other countries. Models of aquifer geometry, geology, groundwater flow, and groundwater quality are developed from observed data. These models are integrated using an economic model of groundwater use and groundwater quality to predict the total economic value of groundwater. This approach to modelling the sustainability of groundwater is demonstrated for the Delta Zone of the groundwater system in the Waimea Plains, Nelson, New Zealand.

Four scenarios of use are investigated; actual, allocated, two-times allocated and five-times allocated. It is predicted that the economic value of irrigation from groundwater in the zone is $\$ 2$ million with actual and allocated water usage. With use of two-times allocated, the economic value of irrigation from groundwater is $\$ 3.5$ million. The Waimea River is predicted to be dry for at least one week in a dry year with this scenario. The economic value of irrigation from groundwater is -\$1.3 million with water use of five times irrigation. This economic loss is due to land being taken out of production because of saltwater intrusion, and the costs of moving a water supply system caused by predicted saltwater intrusion. This research provides key information to assist the water management agency in setting allocation limits for groundwater resources.

\section{Introduction}

Gleick (1993) summarises a number of areas where problems exist with the earth's water supply, including groundwater resources. He claims that we are "falling farther and farther behind" in our efforts to provide more water for the increasing needs of a growing world population. strategic importance. Increasing population densities and agricultural activities have led to greater use of groundwater in the last 50 years (Foster, 2000). This has caused development pressures on groundwater quantity and quality (Sililo, 2000). Groundwater use in New Zealand is growing. For example $50 \%$ of all water allocated in New Zealand since 1990 is from groundwater (Fenemor and Robb, 2001)

Pressure on groundwater systems by users has led to evolving approaches of the management of groundwater systems. The concept of safe yield, defined by Domenico and Schwartz (1990) as: "the rate at which water can be withdrawn from an aquifer for human use without depleting the supply to the extent that withdrawal at this rate is no longer economically feasible" was a management criterion. Today the concept of sustainability of groundwater systems is used to consider groundwater management options. The concept of sustainability has a number of guises that generally consider environmental, economic and social facets of resource use (e.g. Simonovic, 2001).

This paper summarises the legal context of sustainable management in New Zealand and presents an approach to modelling the sustainability of groundwater systems using geological, flow, water quality, and economic models linked using the concept of total economic value. An example is given of modelling the sustainability of groundwater in a part of the Waimea Plains aquifer system, Nelson, New Zealand.

\section{Sustainable management}

Sustainable management under New Zealand's Resource Management Act (1991) Section 5(2) means 'managing the use, development and protection of natural and physical resources in a way, or at a rate, which enables people and communities to provide for their social, economic, and cultural wellbeing and for their health and safety while -

(a) sustaining the potential of natural and physical resources (excluding minerals) to meet the reasonably foreseeable needs of future generations; and

(b) safeguarding the life-supporting capacity of air, water, soil, and ecosystems; and

(c) avoiding, remedying, or mitigating any adverse effects of activities on the environment'.

Regional councils, using regional plans that govern the management of water quantity and quality, carry out groundwater management in New Zealand (Fenemor and Robb 2001), as governed by 
integrated modelling of the physical, biological, and human aspects of a groundwater resource is required for understanding of the sustainability of groundwater systems. Environmental usage invariably involves trade-offs between environmental quality, or quantity, and economic development. Integrated modelling is also required to understand these trade-offs so that rational decisions can be made to allow human usage of the environment while maintaining acceptable environmental standards.

\section{Groundwater models}

Geological models of groundwater systems are typically constructed using computers to model three-dimensional surfaces defined by bore logs or seismic profiling (e.g. Hamilton and Jones, 1992). These models are extremely useful to visualise the complex geometry of groundwater reservoirs. However, the definition of groundwater reservoirs in alluvial sedimentary aquifers is often difficult. 3D interpolation of drill log permeability estimates can yield useful information about aquifer geometry in these cases.

Groundwater flow models incorporate boundary conditions and aquifer properties, and are used to make estimates of the safe yield of groundwater systems. Water inputs into the model, through for example rainfall recharge and river recharge, are balanced with outputs such as use and discharge to the sea. Safe yields are identified by designing simulations that mimic potential management regimes and estimate effects on the reservoir (e.g. groundwater storage) and discharges (e.g. groundwater recharge to rivers).

Groundwater quality models are defined by interpolating observations of groundwater quality in wells. These models represent groundwater quality as a continuum within aquifers or as a continuum within the whole reservoir, or basin.

Other models, for example models of groundwater biota, can be included in the suite of models that are needed to understand sustainability.

Economic models relate water usage to economic benefits (productive values) and water usage to environmental effects (in-situ values). They are often highly region-specific and are best developed using surveys of water users and the general public, available economic data including production and land values, and available social data such as employment and recreation. Economic models are usually based on surveying samples of the population. The aim of the economic model is to simulate the total economic value of the resource.

\section{Total economic value}

The total economic value framework (National Research Council, 1997) uses productive and in-situ values of water to provide a basis for evaluating the economic costs and benefits of changes in water resource management (White et al., 2001). To illustrate, consider a rural community that draws water for irrigation from a fully allocated aquifer. The aquifer is managed so as to maintain a given level of environmental 'benefits'. Let's also assume that the community has asked water managers to reduce total abstractions for irrigation to increase the amount of groundwater left in situ to maintain the environmental benefits. An economic analysis of the proposal would compare what people are willing to pay for the greater environmental benefits against the minimum amount required to compensate the irrigators who face a reduction in their water allocation (the cost). Ouantifvino henefits and costs is relativelv straiohtforward when

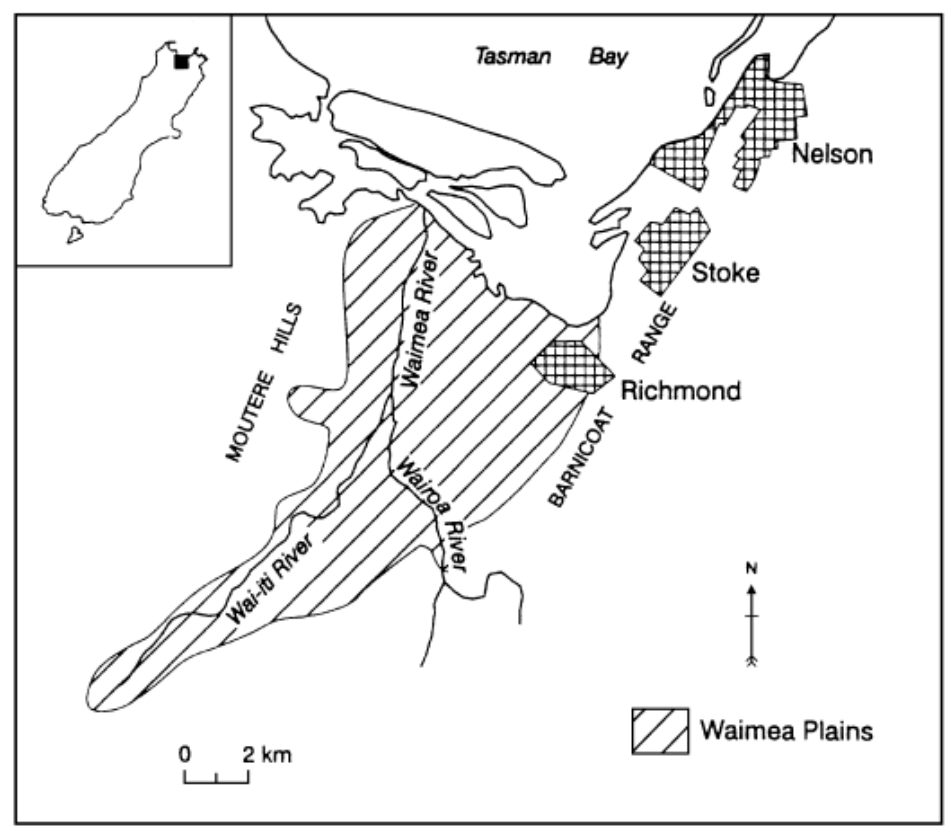

Figure 1 Location of the Waimea Plains, Nelson, New Zealand. Reprinted with the permission of the Journal of Hydrology (New Zealand).

\section{Example of application}

\section{Models}

The Waimea Plains consist of about $75 \mathrm{~km}^{2}$ of productive agricultural land in the northwest of the South Island, New Zealand (Figure 1). Tasman Bay, and the Waimea Inlet, bound the Waimea Plains to the north. Flowing across the Waimea Plains are the Wai-iti, Wairoa, and Waimea rivers. These rivers have deposited flood-plain gravels and formed terraces.

The Tasman District Council is the water management authority in the region. There are a total of 274 wells with lithological logs as of the end of March 1998 (White and Reeves, 1999). Well log information has been recorded predominantly by local drillers, with some holes logged by geologists. Well logs typically report the water-bearing layers; permeable layers are often described as "water-bearing", "poor water-bearing", or "good water-bearing".

These descriptions of layer permeability are used to generate a permeability "log" for each of the 274 wells. Permeable layers are assigned a value of 200 and non-water bearing layers a value of 100 in the permeability "log". Permeability values in the "log" are sampled at intervals of $0.2 \mathrm{~m}$ below the ground surface. Sediments above the water table are assigned a value of 100 or 200 , based on the description of lithology in the well log. Permeability values are modelled in three dimensions with the minimum tension technique on a conformal grid using EarthVision software. The minimum tension technique used by the EarthVision software aims to represent 3-D data values as closely as possible where data exists to estimate plausible values in areas where no data exists.

Contoured surfaces of the 3-D Waimea Plains permeability model represent the complexity of permeability variations in the late Quaternary sediments (Figure 2). Water-bearing zones are plotted in blue, and non-water-bearing zones in red; the model has an upper ............................ 


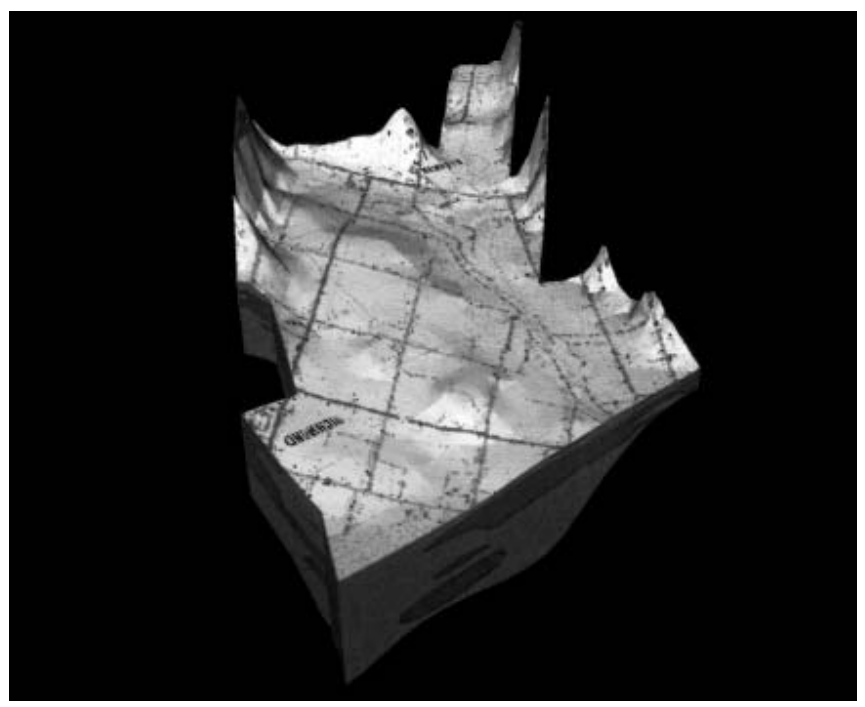

Figure 2 Waimea Plains three-dimensional geological model. Aquifers are shown in blue in the cross-sections.

a uniform grid size of $250 \mathrm{~m}$ by $250 \mathrm{~m}$ and is bounded by constant head and general head boundary conditions. Major water sources are rainfall recharge and inflow from the Wai-iti and Wairoa rivers.

The U.S. Geological Survey's MODFLOW model is used to simulate groundwater flow. The following MODFLOW packages were used to represent the Waimea Plain groundwater flow model: well, general head boundary, drain, recharge, and stream packages. Model parameters were adjusted until simulated hydrologic conditions (Wai-iti River flow and Waimea River flow) were comparable with measured river conditions. The hydrologic conditions considered for calibration included the groundwater levels in monitoring wells.

A 3-D model of nitrate-nitrogen $\left(\mathrm{NO}_{3}-\mathrm{N}\right)$ concentrations in the Waimea Plains was constructed in EarthVision by modelling $\mathrm{NO}_{3}-\mathrm{N}$ concentrations from 14 samples collected by Tasman District Council in 1998. Chemical data is combined with borehole information

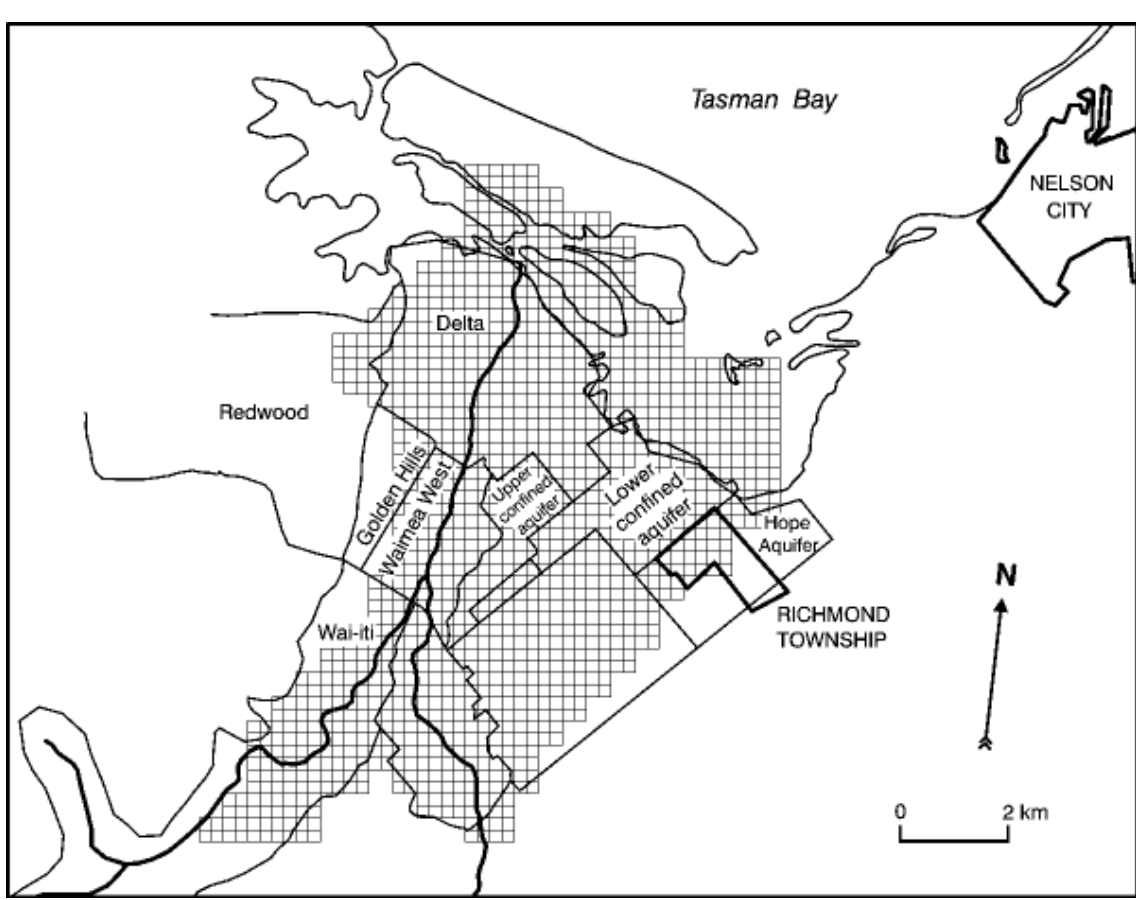

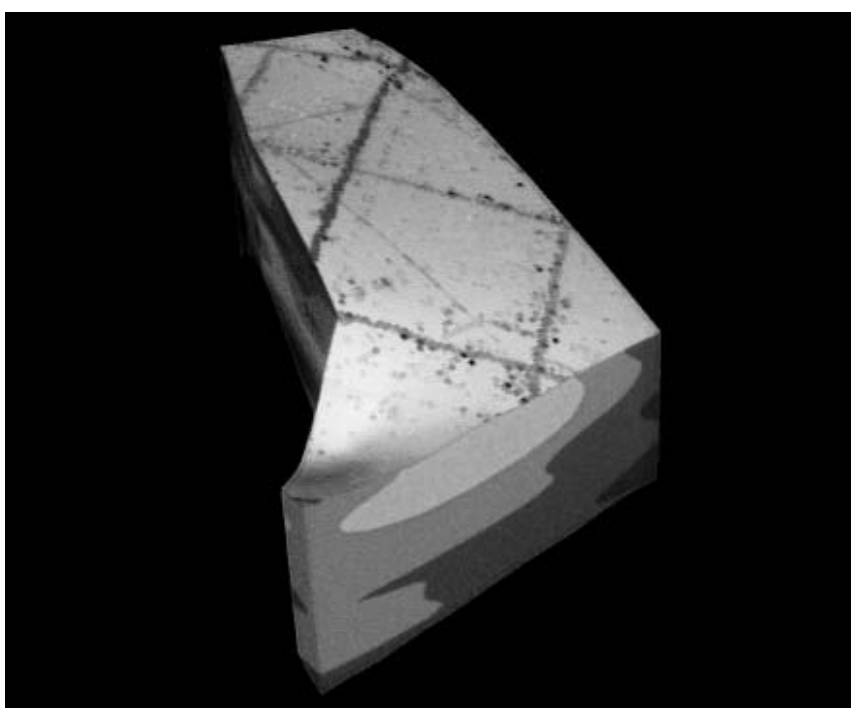

Figure 4 Waimea Plains three dimensional groundwater quality model.

(location, RL elevation and screened intervals) to produce an input file consisting of $\mathrm{NO}_{3}-\mathrm{N}$ in 3-D space. The input file is modelled in EarthVision using the minimum tension gridding technique, with extrapolated areas of the model cut out.

Figure 4 shows a north - south cross-section of the $\mathrm{NO}_{3}-\mathrm{N}$ model. High $\mathrm{NO}_{3}-\mathrm{N}$ concentrations (green) can be seen near the surface of the aquifer and lower $\mathrm{NO}_{3}-\mathrm{N}$ concentrations (blue) at the bottom and from the south. This has been interpreted as $\mathrm{NO}_{3}-\mathrm{N}$ infiltrating from the surface (probably due to fertiliser applications) and dispersing through the aquifer. The low $\mathrm{NO}_{3}-\mathrm{N}$ plume coming from the south is interpreted to be low $\mathrm{NO}_{3}-\mathrm{N}$ water recharging the aquifer from a river just to the south of the model boundary.

An economic model of the Delta Zone is created from analysis of questionnaires completed in face-to-face interviews with farmers (White et al., 2001). A total of 17 (or 18\%) of the 92 irrigators contributed to an economic survey of irrigation in the Delta Zone. The random sample included dairying, sheep, deer, horticulture, grapes, and lifestyle land uses. These irrigators specified the likely effects of reduced groundwater availability and reduced groundwater quality on their farming operation or lifestyle block. In most cases a significantly reduced groundwater availability would lead to significant changes in current land use and consequent reduction in land values. Reductions in groundwater quality, caused for example by saltwater intrusion, would also lead to changes in land uses, and lead to a reduction in land values. These changes quantify the economic value of the groundwater to the users, and to the wider economy.

\section{Sustainability}

An approach to modelling the sustainability of aquifer systems (White, 2001) is illustrated by linking models of the physical and human environment in the Delta Zone of the Waimea Plains groundwater system (as shown in Figure 3). Three-dimensional models of the aquifer structure, groundwater flow, and groundwater quality, are used to predict the environmental effects of four scenarios of groundwater usage. Some facets 
Table 1 Predicted environmental effects of groundwater pumpage, Delta Zone, Waimea Plains, in one week of March 1983.

\begin{tabular}{|l|c|c|c|c|}
\hline \multirow{2}{*}{ Effect } & \multicolumn{4}{c|}{ Pumpage Scenarios } \\
\cline { 2 - 5 } & $\begin{array}{c}\text { Actual } \\
\text { Pumpage }\end{array}$ & $\begin{array}{c}\text { Allocated } \\
\text { Pumpage }\end{array}$ & $\begin{array}{c}\mathbf{2} \text { x } \\
\text { Allocated } \\
\text { Pumpage }\end{array}$ & $\begin{array}{c}\text { Allocated } \\
\text { Pumpage }\end{array}$ \\
\hline $\begin{array}{l}\text { Waimea River flow at the coast, } \\
\left.\text { weekly average ( } \mathrm{L} \mathrm{s}^{-1}\right)\end{array}$ & 280 & 260 & 0 & 0 \\
\hline $\begin{array}{l}\text { Neiman Creek discharge, weekly } \\
\text { average (L s }\end{array}$ & 70 & 70 & 30 & 0 \\
\hline $\begin{array}{l}\text { Groundwater discharge across the } \\
\text { estuary boundary (L s-1) }\end{array}$ & 800 & 800 & 600 & 120 \\
\hline $\begin{array}{l}\text { Area of land with groundwater chloride } \\
\text { concentration above 200 ppm (ha) }\end{array}$ & 0 & 0 & 0 & 481 \\
\hline Area of land with no groundwater (ha) & 0 & 0 & 0 & 126 \\
\hline
\end{tabular}

effects of changes in water quality, for four scenarios of groundwater usage.

Weekly average piezometric levels were simulated for the 1982/1983 year, when March Wairoa River flow was a 1-in-34 year low and 3-monthly rainfall was a 1-in-4 year low, with the MODFLOW groundwater flow model of the Waimea Plains system. The 1982/83 year represents a time when the groundwater system was at its most stressed and therefore is an appropriate period in which to examine the limits of water allocation and the environmental effects of water allocation.

Groundwater pumpage potentially causes environmental effects on: river flow, spring flow, groundwater level near the coast, and groundwater quality. Potential effects are time-variant and the maximum predicted effect occurs in one week of March during the 1982/83 year. The Waimea River is predicted to be dry when pumpage is twice the allocated amount or greater (Table 1). Springfed Neiman Creek is predicted to stop flowing in 23 weeks of the $1982 / 83$ year, when pumpage is five times allocation. Groundwater discharge across the estuary boundary of the Delta Zone is predicted to occur in all four pumpage scenarios (Table 1). However, the simulation of five-times the allocated pumpage predicts that groundwater levels in a substantial area of the Delta Zone will be lower than mean sea level which could allow saltwater intrusion of the groundwater system.

It is predicted that 481 ha of the Delta Zone could have a groundwater $\mathrm{Cl}$ concentration greater than the World Heath Organisation ëmaximum desirable' limit of 200ppm with five-times the

Table 2 Predicted economic effects of four groundwater usage scenarios in the Delta Zone, Waimea Plains. The area of the model Delta Zone $=1513 \mathrm{ha}$.

\begin{tabular}{|l|c|c|c|c|}
\hline \multirow{2}{*}{\multicolumn{1}{|c|}{ Modelled effects }} & \multicolumn{4}{c|}{ Pumpage Scenarios } \\
\cline { 2 - 5 } & $\begin{array}{c}\text { Actual } \\
\text { Pumpage }\end{array}$ & $\begin{array}{c}\text { Allocated } \\
\text { pumpage }\end{array}$ & $\begin{array}{c}\text { Two-times } \\
\text { allocated } \\
\text { pumpage }\end{array}$ & $\begin{array}{c}\text { Five-times } \\
\text { allocated } \\
\text { pumpage }\end{array}$ \\
\hline Area of irrigation (ha) & 490 & 490 & 980 & 906 \\
\hline $\begin{array}{l}\text { Area not irrigable because of no } \\
\text { groundwater availability and/or } \\
\text { saltwater intrusion (ha) }\end{array}$ & 0 & 0 & 81 & 607 \\
\hline Non-irrigated land (ha) & 1023 & 1023 & 452 & 0 \\
\hline $\begin{array}{l}\text { Economic benefit of irrigation, } \\
\text { from (\$ million) }\end{array}$ & 2 & 2 & 3.5 & 3.3 \\
\hline $\begin{array}{l}\text { Economic effect of unavailability } \\
\text { Pf }\end{array}$ & $\mathrm{n}$ & $\mathrm{n}$ & $\mathrm{n}$ & $\begin{array}{c}-2.6 \text { (land prices) } \\
\text { (n) } / \text { Tn }\end{array}$
\end{tabular}
$\$ 4,400 /$ ha. deterioration.

\section{Summary}

allocated pumpage and groundwater would disappear from under 126 ha of farmland.

Economic benefits of increased water availability are estimated using the relation between land values and marginal water availability gained from analysis of questionnaires completed by irrigators in the Delta Zone. For example, irrigated farms in the Delta Zone are estimated to be worth approximately $\$ 4,000$ per hectare more than non-irrigated farms. In addition, Waimea Plains irrigators believe that a decline in groundwater quality will have an impact on property prices because groundwater will not be suitable for household use. Water quality for household use is a significant consideration in property purchase for most farmers including smallholders and irrigators. For example, farmers in the Delta Zone indicated that the mean difference of water property value between pristine groundwater and undrinkable groundwater was approximately equivalent to

The area of the Delta Zone under irrigation is predicted to increase to 980 ha (Table 2) with pumpage of two-times the present allocation. But increasing the pumpage further, to five-times the present allocation, is predicted to result in 906 ha of irrigation, i.e. the land area under irrigation with five-times allocation is less than with two-times allocation. This is because 607 ha of land could need to be retired from irrigation use with five-times allocated pumpage, because the aquifer is predicted to be dry or because of water quality

The net economic benefits of irrigation are estimated as \$2 million with the actual and allocated pumpage scenarios. The net benefit of irrigation with a pumpage of two-times the allocated is estimated to be $\$ 3.5$ million. This is greater with the actual and allocated pumpage scenarios because more land is irrigated in the two-times allocation scenario. The net economic benefit with five-times allocated pumpage is estimated at $-\$ 1.3$ million. This is because of saltwater intrusion and unavailability of groundwater for irrigation would cause a loss of $\$ 2.6$ million in land values. Also saltwater intrusion could result in saline water entering some public water supply wells; these wells would have to be moved to a new site at a cost of $\$ 2$ million (Wareing pers. comm.).

Prediction of the sustainability of groundwater resources requires integration of geological, hydrological, water quality, and economic models.

The example of the Waimea Plains Delta Zone illustrates the integrated use of these various models. Actual and allocated pumpage scenarios will cause similar environmental effects and produce similar economic benefits. Pumpage of two-times the present water allocation could cause the Waimea River to become dry, but will produce a greater economic benefit than the two scenarios with lower pumpage because of increased irrigation. Pumpage of five-times the allocation could cause the Waimea River and Neiman Creek to run dry, and could result 
Research, such as that outlined, plays a part in quantifying the responses of the groundwater system to possible management actions and therefore will assist with decision-making on the sustainable development of this important resource.

\section{Acknowledgements}

Research on the economic value, and sustainability, of groundwater was completed under the Foundation for Research, Science and Technology's Understanding Groundwater Resources programme (contract No. C05813). Thanks are also due to the Tasman District Council and residents of the Waimea Plains.

\section{References}

Domenico, P. A., Schwartz, W., 1990, Physical and Chemical Hydrogeology. J. Wiley and Sons, Inc. 824p.

Fenemor, A. D., Robb, C. A., 2001, Groundwater management in New Zealand. In Groundwaters of New Zealand, M.R. Rosen and P.A. White (eds). New Zealand Hydrological Society Inc., Wellington. www.hydrologynz.org.nz. pp. 273-289.

Foster, S. S. D., 2000, Groundwater resources at the turn of the millennium: taking stock and looking forward. In Groundwater: Past Achievements and Future Challenges. Sililo et al. (eds) Balkema. pp. 27-33.

Gleick, P. H., 1993, An introduction to global fresh water issues. In Water in Crisis a Guide to the World's Fresh Water Resources. Gleick, P.H. (ed) Oxford University Press. pp. 3-12.

Hamilton, D. E., Jones, T. A., 1992, Computer Modelling of Geologic Surfaces and Volumes. The American Association of Petroleum Geologists Computer Applications in Geology, 1. 297p.

National Research Council, 1997, Valuing groundwater: economic concepts and approaches. National Academy Press, Washington. 189p.

Sililo, O., et al., 2000, Groundwater: Past Achievements and Future Challenges. Proceedings of the XXXth IAH congress on groundwater. Cape Town, South Africa, 26 November - 1 December 2000. Balkema. 1144p.

Simonovic, S. P., 2001, Measures of sustainability and their utilization in practical water management planning. Regional Management of Water Resources (Proceedings of a symposium held during the sixth IAHS Scientific Assembly at Maastricht, the Netherlands, July 2001). IAHS Publication $268.288 \mathrm{p}$.

White, P. A., Sharp, B. M. H., Kerr, G. N., 2001, Economic valuation of the Waimea Plains groundwater system. Journal of Hydrology (NZ) 40(1). pp. 59-76.

White, P. A., 2001, Groundwater resources in New Zealand. In Groundwaters of New Zealand, M. R. Rosen and P. A. White (eds). New Zealand Hydrological Society Inc., Wellington, www.hydrologynz.org.nz. pp. 4575.

White, P. A., Reeves, R. R., 1999, Waimea Plains aquifer structure as determined by three-dimensional computer modelling. Journal of Hydrology (NZ) 38(1). pp. 49-75.
Paul A. White graduated from Victoria University of Wellington in 1980 with a BSc (Hons). He joined the Ministry of Works and Development at the Water and Soil Division's Hydrology Centre in 1980 where he worked on the application of geophysical techniques to groundwater investigations. In 1988 he jointed the Department of Scientific and Industrial Research. He is present role at the Institute of Geological and Nuclear Sciences is Groundwater Programme Leader. Present research interests include the application of groundwater models to understanding surface (rainfall and river) water interaction with groundwater, groundwater flow model, validation, computer modelling of aquifer geology, and the application of resource economics to groundwater. He is currently the President of the New Zealand Hydrological Society.

Yoon-Seok Hong was born in 1962, Seoul, Republic of Korea. He received the M. Sc. degree in environmental management from Graduate School of Environmental Studies, Seoul National University, Republic of Korea, in 1987. He received the Ph.D. degree in environmental engineering from Institute of Technology \& Engineering, Massey University, New Zealand. He has been with Institute of Geological and Nuclear Sciences since 1999 as a scientist Imodeller. His primarily expertise is in computer modelling and control of environmental system such as hydrological and groundwater systems and industrial process systems including water and wastewater treatment process, and biological process.

$\boldsymbol{R} \boldsymbol{R}$ Reeves graduated from Victoria University of Wellington with an honours degree in geophysics in 1991. He has worked at GNS in the geothermal and groundwater research programmes since 1994. Within this time, Rob has developed specialist skills in the areas of groundwater sampling, 3-D geological, temperature and water chemistry modelling, and database management.
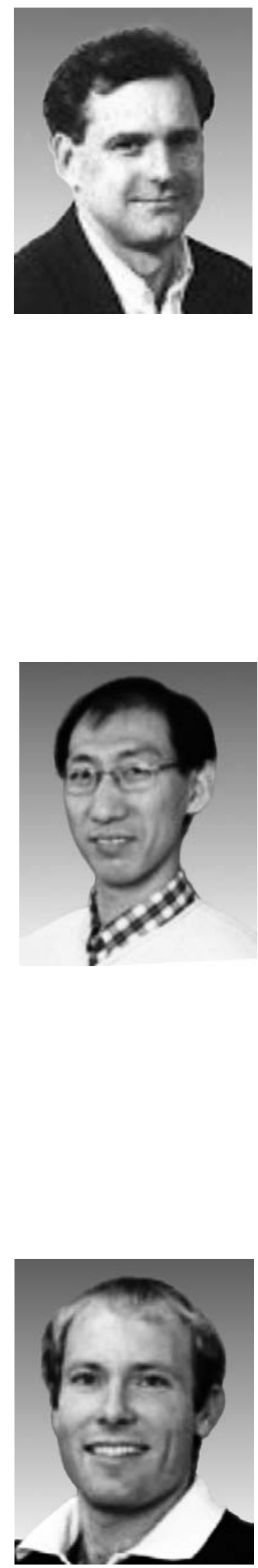